\title{
Characteristics of carcass and non-carcass components of lambs fed diets containing silages of forages adapted to the semi-arid environment
}

\author{
F.S. Campos ${ }^{1 \#, ~ G . G . P . ~ C a r v a l h o ², ~ E . M . ~ S a n t o s ~}{ }^{3}$, G.G.L. Araújo ${ }^{4}$, G.C. Gois ${ }^{5}$, R.A. Rebouças ${ }^{2}$, \\ A.L.R. Magalhães ${ }^{1}$, J.S. Oliveira ${ }^{3}$, T.V. Voltolini ${ }^{4}$, B.M.A. Carvalho ${ }^{6}$ \& A.F. Perazzo ${ }^{7}$ \\ ${ }^{1}$ Federal University Rural of Pernambuco, Animal Production Department, Garanhuns, Pernambuco, Avenue Bom \\ Pastor, s/n - Boa Vista, Garanhuns - PE, Brazil \\ ${ }^{2}$ Federal University of Bahia, Animal Production Department, 40170-115, Salvador, Bahia, Brazil \\ ${ }^{3}$ Federal University of Paraíba, Animal Production Department, Rod. PB - 079, 58397-000 Areia, Paraíba, Brazil \\ ${ }^{4}$ Brazilian Agricultural Research Corporation, EMBRAPA Semiarid, Rodovia BR-428, Km 152, s/n - Countryside, 56302-970, \\ Petrolina, Pernambuco, Brazil \\ ${ }^{5}$ Federal University of San Francisco valley, Postgraduate Program in Veterinary Sciences in the Semi-Arid, Highway BR \\ 407, 56300-000, Petrolina, Pernambuco, Brazil \\ ${ }^{6}$ Federal University of Minas Gerais, Institute of Agricultural Sciences, Avenue universitária, 1000, 39.404-547, Montes \\ Claros, MG, Brazil \\ ${ }^{7}$ State University of Southeast Bahia, Animal Production Department, BA 263, 45700-000, Itapetinga, Bahia, Brazil
}

(Received 4 July 2018; Accepted 27 November 2018; First published online 10 March 2019)

\author{
Copyright resides with the authors in terms of the Creative Commons Attribution 4.0 South African Licence. \\ See: http://creativecommons.org/licenses/by/4.0/za \\ Condition of use: The user may copy, distribute, transmit and adapt the work, but must recognise the authors and \\ the South African Journal of Animal Science.
}

\begin{abstract}
The aim of this study was to evaluate the effects of diets containing silages of forages that are adapted to the semi-arid environment on the characteristics of the carcass and of non-carcass components of 32 mixed-breed lambs at approximately six months old, with an average live weight of $17.61 \pm 2.63 \mathrm{~kg}$. Lambs were assigned to four treatments (diets containing silages of Atriplex nummularia Lind, Cenchrus ciliaris, Gliricidia sepium and Manihot sp.) in a completely randomized design with eight replicates. Animals fed the diet containing old man saltbush showed higher values for the intakes of dry matter (1.080 g/day), crude protein (190 g/day) and total digestible nutrients (740 g/day), body condition score (2.81 points), fatness (2.87 points), carcass conformation (3.19 points), live weight $(29.1 \mathrm{~kg})$, empty bodyweight $(23.41 \mathrm{~kg})$, weights of the commercial cuts neck, shoulder and ribs $(0.46,0.82$ and $1.12 \mathrm{~kg}$, respectively), and skin weight $(1.972 \mathrm{~kg})$. No differences were found between the diets for carcass dressing percentage, external and internal carcass lengths, leg length and circumference, rump circumference and width, chest width and depth, full bodyweight, empty bodyweight, cooling losses, $\mathrm{pH}$ before and after cooling, loin, and leg. Silages of old man saltbush, buffelgrass, gliricidia and pornunça are recommended for inclusion in lamb diets. Diets with old man saltbush silage provide the best results for characteristics of the carcass and of non-carcass components besides weight gain, which can reach up to $200 \mathrm{~g} /$ day depending on the formulation.
\end{abstract}

Keywords: Carcass composition, feedlot, saltbush, sheep

\# Corresponding author: flemingcte@yahoo.com.br

\section{Introduction}

Several plant species with forage potential are found in the caatinga biome of Brazil, but these do not meet the nutritional requirements of animals owing to fluctuations in the quantity and quality of the forage (Souto et al., 2005). Therefore, alternative forage plants that are able to produce in semi-arid conditions should be evaluated to address animal deficiencies.

Traditional forages such as corn (Zea mays) and sorghum (Sorghum bicolor) are frequently used in many regions of Brazil. However, forage plants adapted to the semi-arid region, such as gliricidia (Gliricidia sepium (Jacq)), old man saltbush (Atriplex nummularia Lindl), pornunça (Manihot sp.) and buffelgrass (Cenchrus ciliaris L.), which are tolerant of the temperature and precipitation conditions of that environment, 
are found in abundance. For this reason, and because of their productive and nutritional features, the influence of these crops in the form of silage on meat-related aspects of sheep production should be investigated.

The use of forage plants that are adapted to the semi-arid region, coupled with the practice of ensiling, increases the forage supply, especially during the dry seasons of the year, thereby fostering the sustainability of small-ruminant production. According to Carvalho et al. (2017), silages that contain these roughages are accepted in different degrees by animals, which require the identification of nutritional and production-related responses.

Researchers have evaluated the use of these forage species, fresh and preserved, in various areas of the world (Avilés-Nieto et al., 2013; Maciel et al., 2015; Obeidat et al., 2016; Campos et al., 2017; Moiforay et al., 2017), but information about the efficiency of ruminant production in response to the use of these forages in silage form is still scarce. The use of these silages may yield promising results in production performance, biometric and morphometric parameters, and characteristics of the carcass, fat thickness, yields of cuts, carcass, and non-carcass components. This study was therefore conducted to evaluate the effect of diets that contained silages of forage plants that are adapted to the semi-arid environment on the characteristics of the carcass and of non-carcass components of lambs.

\section{Materials and Methods}

The experiment was conducted at the Experimental Caatinga Field in the Metabolism Unit of the Brazilian Agricultural Research Corporation (EMBRAPA), Petrolina, PE, Brazil. The average annual precipitation in the region is $570 \mathrm{~mm}$, and maximum and minimum temperatures are $33.46{ }^{\circ} \mathrm{C}$ and $20.87^{\circ} \mathrm{C}$, respectively (EMBRAPA, 2011). This study was analysed and approved by the Committee of Ethics in Animal Use (CEUCA) of the School of Veterinary Medicine at the Federal University of Bahia (no. 0005/2016).

A completely randomized experimental design was adopted with four treatments and eight replicates. Thirty-two uncastrated mixed-breed lambs at five months old were used in the trial, with an average initial liveweight of $17.6 \pm 2.63 \mathrm{~kg}$. Lambs were initially vaccinated against clostridial diseases and dewormed against ecto- and endoparasites. Next, they were allotted to individual $1.00 \times 1.20 \mathrm{~m}$ cages with free access to feeders and drinkers. The experiment lasted 59 days, including 10 days for adaptation. During the entire experimental period, the animals were weighed every seven days to monitor their weight development.

The experimental diets were composed of four silages: old man saltbush (Atriplex nummularia Lind), buffelgrass (Cenchrus ciliaris), gliricidia (Gliricidia sepium) and pornunça (Manihot sp.). To produce the silages, the forage plants of old man saltbush, gliricidia, and pornunça were harvested from the experimental field of Embrapa Semi-Arid using the plant shoots, which represent the tenderest leaves and stems, which were $1.5 \mathrm{~m}$ tall. The buffalo grass was harvested at Agricultural Research Company of Paraíba State S.A. (EMEPA) and cut with a backpack mower at $10 \mathrm{~cm}$ above the soil before the inflorescence period, when it was approximately $60 \mathrm{~cm}$ tall. All forage materials were processed through a PP-35 forage harvester to an average particle size of approximately $2.0 \mathrm{~cm}$ and stored in 200-L plastic-drum silos at a compaction density of $600 \mathrm{~kg} / \mathrm{m}^{3}$. The buffalo grass, however, was compacted at a density of $400 \mathrm{~kg} / \mathrm{m}^{3}$ because of its high DM content (40\%).

Table 1 shows the chemical composition of the experimental diets. The roughage to concentrate ratio of diets was $50: 50$. They were formulated to contain $2.67 \mathrm{Mcal} / \mathrm{kg}$ (metabolizable energy), $14.00 \%$ crude protein (CP) in dry matter, and mineral salt ad libitum (Table 1), which aimed at weight gains of $200 \mathrm{~g} / \mathrm{day}^{-1}$ (NRC, 2007).

Feed and water were available ad libitum. The diets were supplied twice daily, at 08:30 and 15:30. Orts were collected and weighed on the following day to determine intake and to adjust the dry matter (DM) to allow for $10 \%$ of orts in the trough. Samples of feed and orts were collected weekly and placed in identified plastic bags, which were stored in a freezer at $-20^{\circ} \mathrm{C}$. After thawing, samples of roughage, concentrate, and orts were pre-dried in a forced-air oven at $55^{\circ} \mathrm{C}$ for 72 hours. Next, they were ground through Wiley mills with $1 \mathrm{~mm}$ sieves and stored in plastic jars with lids, which were labelled for laboratory analyses.

Analyses were carried out at the Laboratory of Animal Nutrition of Embrapa Semi-Arid, following the methodology described by AOAC (2000) for DM (method 967.03), mineral matter (MM) (method 942.05), CP (method 981.10), and ether extract (EE) (method 920.29). Neutral detergent fibre (NDF) and acid detergent fibre (ADF) contents were obtained according to Van Soest et al. (1991), while the concentrations of neutral detergent insoluble nitrogen and acid detergent insoluble nitrogen were obtained by the procedures described by Silva \& Queiroz (2002). 
Table 1 Ingredient proportions and chemical compositions of the experimental diets

\begin{tabular}{|c|c|c|c|c|}
\hline \multirow[b]{2}{*}{ Ingredients } & \multicolumn{4}{|c|}{ Silage } \\
\hline & Old man saltbush & Buffelgrass & Gliricidia & Pornunça \\
\hline \multicolumn{5}{|c|}{ Proportion of ingredients in the diet (\%) } \\
\hline Silage & 50.00 & 50.00 & 50.00 & 50.00 \\
\hline Ground corn & 37.23 & 39.30 & 46.80 & 45.13 \\
\hline Soybean meal & 8.96 & 7.00 & 0.00 & 1.29 \\
\hline Urea & 0.86 & 0.70 & 0.00 & 0.42 \\
\hline Mineral mix ${ }^{c}$ & 1.68 & 1.75 & 1.95 & 1.92 \\
\hline Calcitic limestone & 0.45 & 0.45 & 0.40 & 0.42 \\
\hline Ammonium chloride & 0.84 & 0.85 & 0.85 & 0.83 \\
\hline \multicolumn{5}{|l|}{ Chemical composition (\% DM) } \\
\hline Dry matter & 61.7 & 66.7 & 55.2 & 57.6 \\
\hline Mineral matter & 11.6 & 9.9 & 8.4 & 7.1 \\
\hline Crude protein ${ }^{\mathrm{a}}$ & 15.5 & 15.0 & 14.0 & 16.1 \\
\hline Ether extract ${ }^{\mathrm{a}}$ & 1.8 & 1.8 & 2.5 & 3.4 \\
\hline NDFap $^{a}$ & 31.6 & 36.8 & 28.0 & 26.9 \\
\hline Neutral detergent fibre ${ }^{a}$ & 45.9 & 50.0 & 40.0 & 40.0 \\
\hline Acid detergent fibre ${ }^{a}$ & 22.2 & 25.1 & 21.9 & 23.3 \\
\hline Indigestible neutral detergent fibre ${ }^{a}$ & 25.1 & 18.6 & 18.1 & 15.4 \\
\hline Neutral detergent insoluble nitrogen ${ }^{b}$ & 14.6 & 14.3 & 16.0 & 21.5 \\
\hline Acid detergent insoluble nitrogen ${ }^{b}$ & 11.8 & 12.3 & 12.8 & 15.2 \\
\hline Cellulose $^{\mathrm{a}}$ & 17.1 & 23.0 & 15.7 & 16.1 \\
\hline Hemicellulose $^{a}$ & 23.7 & 24.9 & 18.1 & 16.7 \\
\hline Lignin $^{\mathrm{a}}$ & 7.4 & 3.0 & 7.2 & 10.4 \\
\hline Total carbohydrates ${ }^{a}$ & 71.1 & 73.3 & 75.1 & 73.4 \\
\hline NFCap ${ }^{\mathrm{a}}$ & 39.5 & 36.5 & 47.1 & 46.5 \\
\hline
\end{tabular}

${ }^{\mathrm{a}}$ In \% DM. ${ }^{\mathrm{b}}$ In \% total nitrogen. ${ }^{\mathrm{C}}$ Provides per $\mathrm{kg}$, in active ingredients: calcium: $120 \mathrm{~g}$; phosphorus: $87 \mathrm{~g}$; sodium: $147 \mathrm{~g}$; sulfur: $18 \mathrm{~g}$; copper: $590 \mathrm{mg}$; cobalt: $40 \mathrm{mg}$; chromium: $20 \mathrm{mg}$; iron: 1,800 mg; iodine: $80 \mathrm{mg}$; manganese: $1300 \mathrm{mg}$; selenium: $15 \mathrm{mg}$; zinc: 3800 mg; molybdenum: $10 \mathrm{mg}$; maximum fluoride: $870 \mathrm{mg}$; phosphorus (P) solubility in $2 \%$ (min.) citric acid: 95\%; NDFap: neutral detergent fibre corrected for ash and protein; NFCap: non-fibrous carbohydrates corrected for ash and protein

The lignin content was determined by treating the ADF residue with $72 \%$ sulfuric acid, following Silva \& Queiroz (2002), while the NDF corrected for ash and protein (NDFap) was obtained by following the methodologies described by Licitra et al. (1996) and Mertens (2002). The total carbohydrate (TC) content was estimated according to Sniffen et al. (1992), as follows:

$$
\mathrm{TC}(\% \mathrm{DM})=100-(\% \mathrm{CP}+\% \mathrm{EE}+\% \text { ash }) .
$$

Because of the presence of urea, non-fibrous carbohydrates corrected for ash and protein (NFCap) were calculated as proposed by Hall (2000):

$$
\text { NFCap }=100-[(\% \mathrm{CP}-\% \mathrm{CP} \text { from urea }+\% \text { urea })+\% \text { NDFap }+\% \mathrm{EE}+\% \text { ash. }
$$

The total digestible nutrients (TDN) content was estimated by the following formula proposed by Weiss et al. (1999): 
$\mathrm{TDN}=\mathrm{DCP}+2.25 \times \mathrm{DEE}+\mathrm{DNFC}+\mathrm{DNDF}$,

where: DCP, DEE, DNFC and DNDF are the digestible fractions of CP, EE, non-fibrous carbohydrates and NDF, respectively.

The animals were weighed every 15 days after a solid-feed deprivation period of 12 hours (with access to water) to determine their total weight gain (TWG) and daily weight gain (DWG). The intake of nutritional components was estimated as the difference between the total amount of each component in the supplied feed and in the orts.

In vivo measurements were obtained with the animals standing on a flat surface. The following measurements were taken: body length (distance between the cervico-thoracic joint and the base of the tail), height at the forequarter (distance between the withers region and the distal end of the forelimb), height at the hindquarter (distance between the sacral tuberosity and the distal end of the hindlimb), and chest circumference (measured by taking the sternum and the withers as basis, and passing the tape around the back of the shoulder).

Body condition score was assessed by palpating the back portion of the spine, observing the amount of fat and muscle in the angle formed by the dorsal and transverse processes, and assigning a score of 1 to $5 \pm 0.5$, where 1 represents a very thin animal and 5 an obese animal (Cezar \& Souza, 2007).

At the end of the 49 days in the feedlot, the animals were slaughtered at the abattoir of the Federal Institute of Sertão Pernambucano (IF-Sertão), in Petrolina, PE, at an average weight of $27.16 \mathrm{~kg}$. Prior to slaughter, the lambs were deprived of solid feed, receiving water only, for 16 hours, in accordance with the animal welfare norms. After this time, they were weighed to calculate the slaughter weight (SW).

Slaughter procedures conformed to the current norms established by the Regulation for Industrial and Sanitary Inspection of Animal Products (BRASIL, 2007). Lambs were stunned by brain concussion using a captive bolt pistol, followed by bleeding, skinning and evisceration. Afterwards, their carcasses were weighed to determine the hot carcass weight $(\mathrm{HCW})$. Subsequently, the $\mathrm{pH}$ and internal temperature of the carcass were measured at zero time post mortem at the semimembranosus muscle.

The gastrointestinal tract (GIT) (rumen-reticulum, omasum, abomasum, and small and large intestines), bladder, and gall bladder were emptied and washed to determine the empty body weight (EBW), which was estimated by subtracting the weights of GIT, bladder and gall bladder from the slaughter weight (SW), to then determine the carcass dressing percentage. Non-carcass components were divided into organs, oesophagus and GIT and by-products, as proposed by Cezar \& Souza (2007).

Non-carcass components (blood, head, feet, skin, tongue, heart, pericardium, lungs, trachea, oesophagus, spleen, liver, pancreas, omental fat, mesenteric fat, GIT, kidneys, bladder and attached gland, penis and testicles) were weighed separately for later calculation of the total organ weight to determine their yield relative to the EBW and the SW.

Carcasses were stored in a cold room at $\pm 4{ }^{\circ} \mathrm{C}$ for 24 hours, hung on appropriate hooks spaced 17 $\mathrm{cm}$ apart. During the cooling period, the $\mathrm{pH}$ and the temperature of the carcasses were measured at the semimembranosus muscle 24 hours post mortem. After this period, carcasses were weighed to determine the CCW and cooling loss. Subsequently, these morphological measurements of the carcass were taken: internal carcass length (ICL), external carcass length $(E C L)$, chest width $(C W)$, rump width (RW), chest depth (CD), rump circumference (RC), leg circumference (LC) and leg length (LL). All length and circumference measurements were taken with a tape measure, while the width and depth measurements were obtained with compasses, whose opening was measured with a ruler. The carcass compactness index $(\mathrm{CCl})$ was calculated by the following equation:

$$
\mathrm{CCl}=(\mathrm{CCW} / \mathrm{ICL}) \text {. }
$$

The carcass was assessed subjectively for conformation, fatness, marbling and renal fat following the methodology described by Cezar \& Sousa (2007).

Pelvic-renal fat and kidneys were removed from the carcass, weighed, and their weights were subtracted from the HCW and CCW. Next, the hot and cold carcass yields were calculated.

Carcasses were sawn lengthwise, at the height of the midline, and their left side was weighed and sectioned into five regions, namely leg, loin, ribs, shoulder and neck. The cuts were weighed individually, and the cold half-carcass weight was obtained as the sum of the weights of the five commercial cuts (Cezar \& Souza, 2007). The left half of the carcass was cross-sectioned between the 12th and 13th ribs to reveal the longissimus dorsi muscle, where the fat thickness was determined with digital callipers.

The data were subjected to analysis of variance (ANOVA) and means were compared by Tukey's test at the $5 \%$ probability level, using SAS statistical software (SAS, 2009). 


\section{Results}

Lambs fed the diet with old man saltbush silage had an average total DM intake of $1080 \mathrm{~g} / \mathrm{day}$, which was higher than those obtained with the other diets, whose results were $860 \mathrm{~g} /$ day for the diet with Gliricidia silage and $990 \mathrm{~g} /$ day). The diet that contained buffelgrass silage led to the lowest intake and did not differ statistically from the one that contained gliricidia, which was similar to the diet that contained pornunça silage (Table 2).

Table 2 Mean values for the total intakes of nutritional components by lambs fed diets that contained forages adapted to the semi-arid environment

\begin{tabular}{|c|c|c|c|c|c|c|}
\hline \multirow{2}{*}{ Item $^{a}$} & \multicolumn{4}{|c|}{ Silage } & \multirow{2}{*}{ SEM } & \multirow{2}{*}{$P$-value } \\
\hline & Old man saltbush & Buffelgrass & Gliricidia & Pornunça & & \\
\hline \multicolumn{7}{|l|}{ Intake (g/day) } \\
\hline Dry matter & $1080^{\mathrm{a}}$ & $740^{\mathrm{C}}$ & $860^{b c}$ & $990^{a b}$ & 0.002 & 0.0002 \\
\hline Organic matter & $970^{\mathrm{a}}$ & $660^{\mathrm{c}}$ & $790^{\mathrm{bc}}$ & $920^{a b}$ & 0.019 & 0.0002 \\
\hline Crude protein & $190^{\mathrm{a}}$ & $100^{c}$ & $110^{c}$ & $160^{b}$ & 0.003 & $<0.0001$ \\
\hline Ether extract & $20 \mathrm{~b}$ & $10^{\mathrm{c}}$ & $20 b^{c}$ & $30^{\mathrm{a}}$ & 0.001 & $<0.0001$ \\
\hline NDFap & $260^{a b}$ & $280^{\mathrm{a}}$ & $200^{b}$ & $230^{\mathrm{b}}$ & 0.008 & 0.0410 \\
\hline NFC & $500^{\mathrm{a}}$ & $240^{c}$ & $420^{b}$ & $490^{\mathrm{a}}$ & 0.008 & $<0.0001$ \\
\hline TDN & $740^{\mathrm{a}}$ & $460^{b}$ & $620^{a}$ & $680^{\mathrm{a}}$ & 0.013 & $<0.0001$ \\
\hline
\end{tabular}

Means followed by different superscripts in the same row differ according to Tukey's test at $5 \%$

$P$-value: significant at the $5 \%$ probability level

SEM: standard error of the mean; NDFap: neutral detergent fibre corrected for ash and proteins; NFC: non-fibrous carbohydrates; TDN: total digestible nutrients

The diet that contained old man saltbush silage provided the highest $(P<0.05)$ protein uptake $(190$ g/day), while the diet with pornunça silage was superior (160 g/day) to those with gliricidia ( $110 \mathrm{~g} /$ day) and buffelgrass (100 g/day), which did not differ from each other for this variable.

The energy uptake from the diets, expressed as total digestible nutrients, was higher $(P<0.05)$ for the diets that contained the silages of old man saltbush (740 g/day), pornunça (680 g/day), and gliricidia (620 $\mathrm{g} /$ day), all of which differed from the buffelgrass silage diet (460 g/day). In percentage terms, the diets with old man saltbush, gliricidia and pornunça silages provided TDN contents of $68.3 \%, 71.7 \%$ and $69.1 \%$, respectively, whereas the diet with buffelgrass silage provided the lowest TDN content $(62.9 \%)$.

The body condition of the animals (Table 3 ) was also influenced by the treatments $(P<0.05)$, but the diets with silages of old man saltbush, gliricidia and pornunça did not affect this variable significantly. However, the body condition of lambs consuming the diets with silages of old man saltbush (2.81) and pornunça (2.56) was higher than that of those that consumed buffelgrass silage (1.81), which did not differ from those.

The TWG was strongly influenced by DWG, which differed $(P<0.05)$ among treatments. The best results were obtained by the animals that consumed the diet with old man saltbush silage $(246.3 \mathrm{~g} /$ day), followed by pornunça ( $208.2 \mathrm{~g} /$ day) and gliricidia (203.9 g/day) silages, which did not differ from each other, but provided higher gains than the $135.8 \mathrm{~g} /$ day obtained with buffelgrass silage.

The HCW and CCW varied across treatments $(P<0.05)$. The highest values for these two variables were obtained with the diets that contained silages of old man saltbush, pornunça, and gliricidia (12.99 and $12.68 \mathrm{~kg}, 12.71$ and $12.41 \mathrm{~kg}$, and 11.18 and $10.87 \mathrm{~kg}$, respectively). The lowest results, however, were obtained with the buffelgrass silage $(9.64$ and $9.42 \mathrm{~kg})$ and did not differ from those obtained with the diet that contained gliricidia silage. 
Table 3 Body condition score and biometric and morphometric measurements of lambs fed diets that contained forages that are adapted to the semi-arid environment

\begin{tabular}{lcccccc}
\hline \multirow{2}{*}{ Item (cm) } & \multicolumn{9}{c}{ Silage } & SEM & P-value \\
\cline { 2 - 4 } & Old man saltbush & Buffalo grass & Gliricidia & Pornunça & & \\
\hline Body condition score & 2.81 & 1.81 & 2.18 & 2.56 & 0.002 & 1.089 \\
Body length & 57.15 & 54.31 & 55.25 & 56.31 & 0.796 & 0.531 \\
Height at the forequarter & 60.35 & 62.01 & 60.81 & 65.31 & 0.979 & 0.102 \\
Height at the hindquarter & 61.91 & 64.15 & 62.68 & 66.30 & 0.848 & 0.179 \\
Chest circumference & 70.91 & 67.61 & 70.00 & 70.93 & 1.132 & 0.566 \\
External carcass length & 54.37 & 54.37 & 53.37 & 56.60 & 0.740 & 0.1432 \\
Internal carcass length & 57.31 & 55.94 & 55.87 & 57.26 & 0.573 & 0.2932 \\
Leg length & 39.49 & 39.79 & 39.50 & 41.04 & 0.501 & 0.1733 \\
Rump circumference & 56.65 & 52.67 & 54.14 & 55.27 & 0.678 & 0.0812 \\
Rump width & 21.27 & 19.75 & 20.12 & 20.56 & 0.257 & 0.1169 \\
Maximum chest width & 19.95 & 17.69 & 18.99 & 19.29 & 0.335 & 0.0759 \\
Chest depth & 23.80 & 22.80 & 23.16 & 24.74 & 0.330 & 0.3626 \\
Leg circumference & 27.27 & 26.28 & 26.12 & 26.63 & 0.475 & 0.6183 \\
\hline
\end{tabular}

Means followed by different superscripts in the same row differ according to Tukey's test at 5\%

SEM: standard error of mean

The silages did not influence carcass dressing percentage, hot and cold carcass yields, and cooling loss $(\mathrm{CL})$, all expressed in percentage terms, $\mathrm{pH}$ measured at 0 hours and 24 hours post-slaughter and carcass compactness index.

The highest carcass weights were found in the lambs that consumed the old man saltbush diet (29.21, 23.41, 12.99 and $12.68 \mathrm{~kg}$ ), while the lowest were observed in those fed the diet that contained buffelgrass silage $(24.31,17.44,9.64$ and $9.42 \mathrm{~kg}$ ). The average $\mathrm{CL}$ in this experiment was $2.87 \%$, which could be because the diets possibly provided similar deposition of adipose tissue.

Carcass compactness index values were similar $(P>0.05)$ among the silages, averaging $0.20 \mathrm{~kg} / \mathrm{cm}$. This measurement is used to evaluate muscle production between animals with a similar liveweight.

Marbling, carcass conformation, fatness, amount of renal fat, and fat thickness (Table 4) were affected $(P<0.05)$ by the diets, with the best values being found in the carcasses of animals fed diets that contained old man saltbush silage $(2.56,3.19,2.06$, and 2.87 , respectively). The lowest results for those variables were observed in the lambs that received the diet that contained buffelgrass silage $(1.75,1.56,1.19$ and 1.56, respectively), which did not differ from the animals consuming the diets with gliricidia and pornunça silages. Results for carcass fatness were similar $(P>0.05)$ among the diets that contained old man saltbush, gliricidia, and pornunça silages, which characterizes homogeneity of fatness. No effect was observed $(P$ $<0.05$ ) between the treatments for the thickness of the carcass fat layer, which ranged from 0.87 to $1.19 \mathrm{~mm}$. In the subjective assessment of perirenal fat, a difference was observed $(P<0.05)$ between the silages, with the lowest values found in the carcasses of the animals fed buffelgrass (1.56) and the highest in the lambs that consumed old man saltbush (2.87). This group did not differ from those that consumed diets that contained silages of gliricidia (2.31) and pornunça (2.44) for this variable.

There was an effect $(P<0.05)$ of silages on the weights of the commercial cuts (Table 5$)$, which varied with the presence of silage in the diets. Neck weight was higher for the diets that contained the silages of old man saltbush, pornunça, and gliricidia, whose values were $0.68,1.09$ and $1.57 \mathrm{~kg}$, respectively, while the shoulder weights were $0.68,1.06$, and $1.48 \mathrm{~kg}$ and rib weights were $0.57,0.94$ and $1.36 \mathrm{~kg}$. The lowest values were observed in the lambs fed the diet that contained buffelgrass silage $(0.46,0.82$ and $1.12 \mathrm{~kg})$, which did not differ from the weights of neck and shoulder in the animals that consumed gliricidia silage. The rib weight did not differ between the animals that received the diets that contained silages of pornunça and gliricidia. 
Table 4 Characteristics of the carcass, subjective assessment and subcutaneous fat thickness of lambs fed diets that contained forages that are adapted to the semi-arid environment

\begin{tabular}{|c|c|c|c|c|c|c|}
\hline \multirow{2}{*}{ Item } & \multicolumn{4}{|c|}{ Silage } & \multirow{2}{*}{ SEM } & \multirow{2}{*}{$P$-value } \\
\hline & Old man saltbush & Buffelgrass & Gliricidia & Pornunça & & \\
\hline Initial bodyweight (kg) & 18.0 & 17.6 & 16.1 & 18.6 & 0.950 & 0.491 \\
\hline Final bodyweight $(\mathrm{kg})$ & $29.7^{\mathrm{a}}$ & $24.3^{\mathrm{b}}$ & $27.4^{\mathrm{ab}}$ & $27.7^{\mathrm{ab}}$ & 0.913 & 0.006 \\
\hline Empty bodyweight (kg) & $23.4^{\mathrm{a}}$ & $17.4^{\mathrm{b}}$ & $19.2^{\mathrm{ab}}$ & $21.8^{\mathrm{ab}}$ & 0.685 & 0.008 \\
\hline Total weight gain & $11.6^{\mathrm{a}}$ & $6.7^{\mathrm{b}}$ & $9.8^{\mathrm{a}}$ & $10.1^{\mathrm{a}}$ & 0.257 & 0.0003 \\
\hline Average daily gain (g/day) & $243.6^{\mathrm{a}}$ & $135.8^{c}$ & $203.9^{b}$ & $208.2^{b}$ & 4.683 & $<0.0001$ \\
\hline Carcass dressing (\%) & 55.49 & 55.27 & 58.35 & 58.24 & 0.024 & 0.974 \\
\hline Hot carcass weight $(\mathrm{kg})$ & $12.99^{\mathrm{a}}$ & $9.64^{b}$ & $11.18^{\mathrm{ab}}$ & $12.71^{\mathrm{a}}$ & 0.452 & 0.025 \\
\hline Hot carcass yield (\%) & 44.47 & 39.65 & 40.79 & 45.86 & 0.033 & 0.786 \\
\hline Cold carcass weight $(\mathrm{kg})$ & $12.68^{\mathrm{a}}$ & $9.42^{\mathrm{b}}$ & $10.87^{\mathrm{ab}}$ & $12.41^{\mathrm{a}}$ & 0.433 & 0.007 \\
\hline Cold carcass yield (\%) & 43.40 & 38.74 & 39.65 & 44.78 & 0.027 & 0.323 \\
\hline Cooling loss (\%) & 2.40 & 2.29 & 2.79 & 2.35 & 0.168 & 0.260 \\
\hline $\mathrm{CCl}(\mathrm{kg} / \mathrm{cm})$ & 0.22 & 0.18 & 0.19 & 0.21 & 0.007 & 0.038 \\
\hline $\mathrm{pH}_{\mathrm{oh}}$ & 6.7 & 6.7 & 6.8 & 6.7 & 0.017 & 0.382 \\
\hline $\mathrm{pH}_{24 \mathrm{~h}}$ & 5.6 & 5.6 & 5.6 & 5.6 & 0.034 & 0.561 \\
\hline Marbling & $2.56^{\mathrm{a}}$ & $1.75^{\mathrm{b}}$ & $2.00^{\mathrm{ab}}$ & $2.69^{\mathrm{a}}$ & 0.0043 & 0.045 \\
\hline Carcass conformation & $3.19^{\mathrm{a}}$ & $1.56^{\mathrm{b}}$ & $2.31^{\mathrm{ab}}$ & $2.44^{\mathrm{ab}}$ & 0.0474 & 2.38 \\
\hline Fatness & $2.06^{\mathrm{a}}$ & $1.19^{b}$ & $1.81^{\mathrm{a}}$ & $1.81 \mathrm{a}$ & 0.0014 & 0.049 \\
\hline Fat thickness (mm) & 1.19 & 0.87 & 0.87 & 1.00 & 0.5736 & 0.068 \\
\hline Renal fat & $2.87^{\mathrm{a}}$ & $1.56^{\mathrm{b}}$ & $2.31^{\mathrm{ab}}$ & $2.44^{\mathrm{ab}}$ & 0.0022 & 1.72 \\
\hline
\end{tabular}

Means followed by different superscripts in the same row differ according to Tukey's test at 5\%

SEM: standard error of mean; $\mathrm{CCl}$ : carcass compactness index

The results for the yields and weights of loin and leg did not differ $(P>0.05)$ between the treatments (Table 5). Mean values for the variables obtained with the diets that contained old man saltbush, pornunça, gliricidia and buffelgrass were $0.68 \%$ and $2.00 \mathrm{~kg}, 0.63 \%$ and $1.96 \mathrm{~kg}, 0.59 \%$ and $1.75 \mathrm{~kg}$, and $0.52 \%$ and $1.57 \mathrm{~kg}$, respectively. The average yields of neck and ribs were $11.02 \%$ and $25.61 \%$, respectively, and the buffelgrass silage provided the best yields of these cuts.

The weights of reproductive tract, liver, heart, and kidneys were affected $(P<0.05)$ by the presence of silage in the diets (Table 6). The weight of the reproductive tract did not differ among the diets that contained old man saltbush, gliricidia and pornunça silages. Aside from the diet that contained gliricidia silage, all treatments provided better results than the one that contained buffelgrass silage $(137 \mathrm{~g})$, which resulted in the lowest weight.

Better results for the liver, heart, and kidney weights were obtained with the diets that contained silages of old man saltbush $(0.526,0.118$ and $0.098 \mathrm{~kg})$, pornunça $(0.462,0.125$ and $0.100 \mathrm{~kg})$ and gliricidia $(0.465,0.105$ and $0.080 \mathrm{~kg})$. The lowest weights of those organs were found in the animals fed buffelgrass silage $(0.296,0.092$ and $0.079 \mathrm{~kg}$ ), except for the kidneys, the results of which were similar to those of the animals fed the diet that contained gliricidia silage.

The total organ weight $($ TOW) was affected by the silages $(P<0.05)$, with the lowest values being obtained with buffelgrass $(1.66 \mathrm{~kg})$. The Total body weight: Slaughter weight and total body weight: Empty body weight ratios were not affected $(P>0.05)$ by the diets. The highest values were obtained by animals fed the diet with gliricidia silage. 
Table 5 Weight and yields of commercial cuts from the carcass of lambs fed diets that contained forages adapted to the semi-arid environment

\begin{tabular}{|c|c|c|c|c|c|c|}
\hline & \multicolumn{4}{|c|}{ Silage } & \multirow{2}{*}{ SEM } & \multirow{2}{*}{$P$-value } \\
\hline & Old man saltbush & Buffelgrass & Gliricidia & Pornunça & & \\
\hline \multicolumn{7}{|c|}{ Weight of commercial cuts (kg) } \\
\hline Neck & $0.68^{a}$ & $0.46^{b}$ & $0.57^{\mathrm{ab}}$ & $0.68^{a}$ & 0.035 & $<0.001$ \\
\hline Shoulder & $1.09^{\mathrm{a}}$ & $0.82^{b}$ & $0.94^{\mathrm{ab}}$ & $1.06^{\mathrm{a}}$ & 0.022 & 0.019 \\
\hline Ribs & $1.57^{\mathrm{a}}$ & $1.12^{b}$ & $1.36^{\mathrm{ab}}$ & $1.48^{\mathrm{ab}}$ & 0.064 & 0.030 \\
\hline Loin & 0.68 & 0.52 & 0.59 & 0.63 & 0.029 & 0.605 \\
\hline Leg & 2.00 & 1.57 & 1.75 & 1.96 & 0.069 & 0.051 \\
\hline \multicolumn{7}{|c|}{ Yield of commercial cuts (\%) } \\
\hline Neck & $11.36^{\mathrm{a}}$ & $10.17^{b}$ & $10.90^{\mathrm{ab}}$ & $11.65^{\mathrm{a}}$ & 0.405 & 0.001 \\
\hline Shoulder & $18.08^{\mathrm{ab}}$ & $18.32^{\mathrm{a}}$ & $17.97^{\mathrm{b}}$ & $18.19^{\mathrm{a}}$ & 0.685 & 0.019 \\
\hline Ribs & $26.03^{a}$ & $24.81^{b}$ & $26.10^{a}$ & $25.51^{a}$ & 1.190 & 0.030 \\
\hline Loin & 11.25 & 11.55 & 11.40 & 10.91 & 0.318 & 0.180 \\
\hline Leg & 33.26 & 35.12 & 33.56 & 33.71 & 0.409 & 1.535 \\
\hline
\end{tabular}

Means followed by different superscripts in the same row differ according to Tukey's test at $5 \%$

SEM: standard error of the mean

Table 6 Mean values for the absolute weights of organs $(\mathrm{kg})$, gastrointestinal tract, by-products, and fat deposits in lambs fed diets that contained forages adapted to the semi-arid environment

\begin{tabular}{|c|c|c|c|c|c|c|}
\hline \multirow{2}{*}{ Item (kg) } & \multicolumn{4}{|c|}{ Silage } & \multirow{2}{*}{ SEM } & \multirow{2}{*}{$\begin{array}{c}P \text { - } \\
\text { value }\end{array}$} \\
\hline & $\begin{array}{l}\text { Old man } \\
\text { saltbush }\end{array}$ & Buffelgrass & Gliricidia & Pornunça & & \\
\hline Reproductive tract & $0.326^{\mathrm{a}}$ & $0.137^{b}$ & $0.224^{\mathrm{ab}}$ & $0.286^{\mathrm{a}}$ & 0.019 & 0.004 \\
\hline Bladder & 0.013 & 0.009 & 0.009 & 0.009 & 0.001 & 0.107 \\
\hline Respiratory tract & 0.610 & 0.479 & 0.523 & 0.573 & 0.022 & 0.077 \\
\hline Spleen & 0.435 & 0.387 & 0.421 & 0.462 & 0.003 & 0.351 \\
\hline Pancreas & 0.220 & 0.197 & 0.217 & 0.225 & 0.001 & 0.182 \\
\hline Liver & $0.526^{\mathrm{a}}$ & $0.296^{\mathrm{b}}$ & $0.465^{a}$ & $0.462^{\mathrm{a}}$ & 0.019 & 0.001 \\
\hline Heart & $0.118^{\mathrm{ab}}$ & $0.092^{b}$ & $0.105^{a b}$ & $0.125^{\mathrm{a}}$ & 0.006 & 0.021 \\
\hline Kidneys & $0.098^{\mathrm{ab}}$ & $0.079^{b}$ & $0.080^{b}$ & $0.100^{\mathrm{a}}$ & 0.004 & 0.034 \\
\hline Gastrointestinal tract & 2.30 & 1.93 & 1.94 & 2.24 & 0.169 & 0.065 \\
\hline Blood & 0.928 & 0.900 & 0.962 & 1.080 & 0.022 & 0.348 \\
\hline Skin & $1.972^{\mathrm{a}}$ & $1.342^{b}$ & $1.573^{\mathrm{ab}}$ & $1.761^{\mathrm{a}}$ & 0.044 & 0.018 \\
\hline Head & 1.530 & 1.349 & 1.388 & 1.543 & 0.182 & 0.068 \\
\hline Feet & 0.651 & 0.573 & 0.611 & 0.645 & 0.037 & 0.481 \\
\hline Tail & 0.100 & 0.093 & 0.093 & 0.087 & 0.020 & 0.232 \\
\hline Renal fat & $0.268^{a}$ & $0.116^{b}$ & $0.236^{\mathrm{a}}$ & $0.290^{\mathrm{a}}$ & 0.015 & 0.042 \\
\hline Omental fat & $0.321^{a}$ & $0.243^{b}$ & $0.405^{\mathrm{a}}$ & $0.382^{\mathrm{a}}$ & 0.033 & 0.040 \\
\hline Total body weight $(\mathrm{kg})$ & $2.333^{\mathrm{a}}$ & $1.667^{\mathrm{b}}$ & $2.035^{\mathrm{ab}}$ & $2.233^{\mathrm{a}}$ & 0.086 & 0.0062 \\
\hline Total body weight: Slaughter Weight (\%) & 12.52 & 14.58 & 13.46 & 12.40 & 0.656 & 0.77 \\
\hline Total body weight: Empty body weight (\%) & 10.03 & 14.58 & 13.47 & 9.771 & 1.143 & 0.525 \\
\hline
\end{tabular}

Means followed by different superscripts in the same row differ according to Tukey's test at 5\%

SEM: standard error of the mean 
No differences were observed $(P>0.05)$ for the weights of GIT, blood, head, feet, and tail between the groups (Table 6). Skin weight differed $(P<0.05)$ among the animals receiving the treatments, but higher values were found in those fed diets that contained the silages of old man saltbush $(1.972 \mathrm{~kg})$, pornunça $(1.761 \mathrm{~kg})$, and gliricidia $(1.573 \mathrm{~kg})$ compared with the lambs fed the diet that contained buffelgrass silage $(1.342 \mathrm{~kg})$.

The silages used in the diets led to significant differences in the amounts of renal and omental fats, which were lower $(P<0.05)$ in the lambs fed the buffelgrass silage $(0.116$ and $0.243 \mathrm{~kg})$.

\section{Discussion}

The higher DM intake of the lambs fed old man saltbush and pornunça silages contributed to their higher intakes of crude protein, non-fibrous carbohydrates and total digestible nutrients, which corroborated the findings of Souto et al. (2005), who evaluated the use of old man saltbush in lamb diets. The results of this study suggest high acceptability of this halophytic forage, which can be verified by the satisfactory DM intake. Additionally, according to Ventura et al. (2014), the form in which salt is presented in halophytic forages is important in their acceptance by animals.

The differences $(P<0.05)$ among the protein levels, with higher results being obtained with the diet that contained old man saltbush, may be a consequence of DM intake, since the diets were formulated to be isoproteic.

The results for the body condition of the animals, with higher values being found in those fed the diets with old man saltbush and pornunça silages, may be explained by their higher intakes of DM, protein and total digestible nutrients, which possibly resulted from the better palatability of these diets (Table 3 ).

No differences were observed among the morphometric parameters, possibly because the animals received the experimental diets only in the finishing stage. At that time, they had a homogenous body size resulting from puberty, when bone growth ceases and muscle development begins, which is later intensified by the filling of adipocytes, triggering fat deposition in the carcass.

The observed results for weight gain are a consequence of the nutrient uptake, expressed by the daily intakes of DM and CP, and, in particular, of total digestible nutrients (Table 2) from the silages of old man saltbush, gliricidia and buffelgrass, respectively. It was clear that the animals with lower total and daily weight gains were those fed the diet that contained buffelgrass, which can be explained by their lower energy intake. This finding corroborates that of Flakemore et al. (2015), who declared that a decline in performance may be a consequence of a lower TDN intake.

The results found for carcass dressing do not suggest differences among the diets, which contrasts with the reports of Oliveira et al. (2015), who mentioned the possibility of the diet influencing both the quantitative and the qualitative aspects of ruminant meat. The values observed here disagree with those reported by Penha et al. (2005), who concluded that carcass weight influences significantly the non-carcass components, carcass dressing percentage, subjective conformation, fatness, and most of the carcass measurements.

In the ovine species, hot carcass yield ranges from $40 \%$ to $50 \%$, depending on the carcass conformation, which involves the development and profile of muscle masses and the quantity and distribution of fat cover (AHDB Beef \& Lamb, 2012). The carcass yields obtained in this experiment corroborate those estimated by these authors.

Cooling loss is inversely related to the degree of fatness of a carcass, as the fat cover protects it during the cooling period, reducing losses. In this study, the $C L$ of the carcasses from all treatments was lower than 4\%, which, according to Lage et al. (2014), indicates an adequate level of protection.

According to Strydom et al. (2016), the $\mathrm{pH}$ decline during the rigor mortis process in the carcass influences meat quality directly, mainly because of the glycogen reserve, $\mathrm{pH}$, and the temperature of the muscle. The final $\mathrm{pH}$ values in the present study indicate that the development of rigor mortis was adequate during the chilling process, which results in meat with more desirable sensory properties for regular consumption and for the processing industry.

The intramuscular fat might have greatly contributed to the final quality of the meat. However, its excess can modify the product's taste. In this study, intramuscular fat ranged between 1.75 and 2.69 points, which are considered low values, varying between too little to good marbling. Montossi et al. (2013) stated that the degree of fatness is an indicator of the tissue composition of the carcass inasmuch as it is associated with the amount of meat in it, since muscle and fat contents in the carcass are related inversely. Therefore, a larger proportion of fat in the carcass means less muscle.

Regardless of the type of silage used in the diet, the carcasses of the animals tested in this experiment were considered thin, with conformation ranging from very poor to good. However, the animals 
were still in the muscle-development phase, consequently accumulating fat, with an average weight of $27 \pm$ $16 \mathrm{~kg}$. Nevertheless, even with values that are considered low in relation to those found for animals of specialized breeds, given the current preference of consumers for lean meats or meats with little fat, this value can be considered satisfactory.

No effect was observed $(P<0.05)$ between the diets for carcass fat thickness, which agrees with Maciel et al. (2015), who observed that the subcutaneous fat tissue in tropical wool-less sheep is not well developed and is deposited almost completely in body cavities in the form of pelvic fat. For sheep carcasses, there is not yet a standard value for minimum cover-fat thickness. However, an adequate amount of fat influences the commercial value directly, while excess fat leads to depreciation of the carcass. Excess fat leads to decreased energy efficiency (Rippol et al., 2010), elevating the nutritional cost of diets, which did not occur in the current study.

In the subjective assessment of perirenal fat, differences were observed $(P<0.05)$ among the diets, with lower values being seen in the animals fed the diet that contained buffelgrass silage. This is a favourable occurrence, since this cavity fat is not sold, generating losses.

Leg and loin are the cuts of highest commercial values and thus called 'prime' or 'first-class' cuts, given their better muscle yield and tenderness. The lower weight gain found in the lambs fed the buffelgrass diet can be explained by their lower intakes of DM and TDN (Table 2), corroborating the assertion of Flakemore et al. (2015) that a reduction of weight gain may be a consequence of lower energy intake.

In the current study the values obtained for the yields of leg, loin, and shoulder of the lambs fed silages of old man saltbush, buffelgrass, gliricidia and pornunça were $62.4 \%, 64.9 \%, 63.1 \%$ and $62.9 \%$, respectively. These values are in line with the recommendation of Silva Sobrinho et al. (2005), who postulated that the average of these yields in meat breeds should be greater than $60 \%$. The average in the current study was $63.5 \%$, suggesting that, despite being mixed breed, the animals had similar yields of prime cuts to those observed in breeds that specialized in meat production.

Because the animals used in this experiment were young and had an average slaughter weight of 27 $\mathrm{kg}$, this probably enabled the observation of the diet effect on these organs, since the lambs fed the diet based on buffelgrass silage and concentrate obtained the lowest average daily gain, the lowest slaughter weight, and consequently lower energy intakes. The growth of organs such as liver, kidneys and gastrointestinal tract implies changes in weight when the animal is offered feed at levels greater than those required for maintenance, while considerable atrophy is observed when they are fed at levels below those needed for maintenance (Black, 1989).

Although the percentage of the total body weight as a function of SW was impressive (Table 6), it might have been underestimated, since slaughter weight includes the weight of the gastrointestinal content, which is not a component of live weight. The total body weight: Empty body weight ratio, however, confirms this representativeness, as it is a measure with greater precision for this assessment.

All results for the lamb skin weight (Table 6) were lower than those observed by Araújo Filho et al. (2007), who evaluated Morada Nova sheep, and obtained a mean value of approximately $2.33 \mathrm{~kg}$. The difference between the mean skin weight values obtained here and those reported in the literature is believed to be due to the growth of animals at slaughter. Results pertaining to the depositions of renal and omental fat are probably correlated with the final weight of the animals, which consumed lower amounts of feed. This led to lower availability of energy in the form of glucose, which compromises lipogenesis and visceral fat deposition.

Sheep that are adapted to a semi-arid environment such as the animals in the present study have the ability to accumulate energy reserves in the form of abdominal fat. In periods of food scarcity, abdominal fat is more easily metabolized than subcutaneous fat (Sami et al., 2013). The increase in the amount of abdominal fat proves the physiological ability of these animals to deposit intra-abdominal fat. According to Anderson et al. (2015), deposition of internal fat is undesirable, since this tissue has no commercial value and its weight influences the weights and yields of the carcass. Moreover, these fats contain high levels of saturated fatty acids and are not used for human consumption.

\section{Conclusions}

Silages of old man saltbush, buffelgrass, gliricidia and pornunça - forage plants adapted to the semiarid environment - are recommended for inclusion in lamb diets. Among them, the silages of old man saltbush, pornunça and gliricidia yield the best results for characteristics of the carcass and of non-carcass components, providing daily gains of up to $200 \mathrm{~g}$ per animal, according to the diet formulation.

\section{Authors' Contributions}

FS, GCG and AFF participated in designing the study, laboratory analysis, and manuscript writing. EMS; GGPC and GGLA Involvement in drafting and revising the manuscript for important intellectual content. JSO; ALRM and TVV 
Data analysis and interpretation. Involvement in the preparation and revision of the manuscript. BMAC, RRA contributions to the acquisition, analysis and interpretation of data.

\section{Conflict of Interest Declaration}

The authors declare that they have no competing interests.

\section{References}

AHDB Beef \& Lamb, 2012. Understanding lambs \& carcasses for better returns. Agriculture and Horticulture Development Board (AHDB), Warwickshire, UK.

Anderson, F.L., Pannier, D.W. \& Pethick, G.E., 2015. Intramuscular fat in lamb muscle and the impact of selection for improved carcass lean meat yield. Anim. 9, 1081-1090. http://dx.doi.org/10.1017/S1751731114002900.

AOAC, 2000. Official Methods of Analysis. 12th ed. Association of Official Analytical Chemists, Washington, DC. $1094 \mathrm{pp}$.

Araújo Filho, J.T.D., Costa, R.G., Fraga, A.B., Sousa, W.H., Gonzaga Neto, S., Batista, A.S.M. \& Cunha, M.G.G., 2007. Effect of the diet and genotype on body measurements and non-constituents of carcass of woolless lambs finished in a feedlot. Rev. Bras. Saúde Prod. Anim. 8, 394-404. http://dx.doi.org/10.1590/S151635982010001200029.

Avilés-Nieto, J.N., Valle-Cerdán, J.L., Castrejón-Pineda, F., Angeles-Campos, S. \& Vargas-Bello-Pérez, E., 2013. Digestibility of Buffelgrass (Cenchrus ciliaris)-based diets supplemented with four levels of Gliricidia sepium hay in hair sheep lambs. Trop. Anim. Health Prod. 45, 1357-1362. http://dx.doi.org/10.1007/s11250-013-0369-4.

Black, J.L., 1989. Crecimiento y desarrollo de corderos. In: W. Haresing (ed). Producción ovina, AGT Editor, México. $592 \mathrm{pp}$.

BRASIL, 2007. Ministry of Agriculture Livestock and Supply. Regulation of the Industrial and Sanitary Inspection of Products of Animal Origin. Brasília, DF. 252 p.

Campos, F.S., Carvalho, G.G.P., Santos, E.M., Araújo, G.G.L., Gois, G.C., Rebouças, R.A., Leão, A.G., Santos, S.A., Oliveira, J.S., Leite, L.C., Araújo, M.L.G.M.L., Cirne, L.G.A., Silva, R.R. \& Carvalho, B.M.A., 2017. Influence of diets with silage from forage plants adapted to the semi-arid conditions on lamb quality and sensory attributes. Meat Sci. 124, 61-68. http://dx.doi.org/10.1016/j.meatsci.2016.10.011.

Carvalho, G.G.P., Rebouças, R.A., Campos, F.S., Santos, E.M., Araújo, G.G.L., Gois, G.C., Oliveira, J.S., Oliveira, R.L., Rufino, L.M.A., Azevedo, J.A.G. \& Cirne, L.G.A., 2017. Intake, digestibility, performance, and feeding behavior of lambs fed diets containing silages of different tropical forage species. Anim. Feed Sci. Technol. 228, 140-148. https://doi.org/10.1016/j.anifeedsci.2017.04.006.

Cezar, M.F. \& Sousa, W.H., 2007. Sheep and goat carcasses - Obtaining, evaluating and classifying. 1st edition. Uberaba Publishing Company Agropecuária Tropical, Uberaba, MG. 231p.

EMBRAPA, 2011. Brazilian Agricultural Research Corporation. Weather data http://www.cpatsa.embrapa.br:8080/servicos/dadosmet/ceb-dia.html. Accessed 17 March 2018.

Flakemore, A.R., Otto, J.R., Suybeng, B., Balogun, R.O., Malau-Aduli, B.S., Nichols, P.D. \& Malau-Aduli, A.E.O., 2015. Performance and carcass characteristics of Australian purebred and crossbred lambs supplemented with rice bran. J. Anim. Sci. Technol. 57, 1-9. https://doi.org/10.1186/s40781-015-0069-x.

Hall, M.B., 2000. Calculation of non-structural carbohydrate content of feeds that contain non-protein nitrogen. University of Florida, Gainesville. p. A-25. (Bulletin 339).

Lage, J.F., Paulino, P.V., Pereira, L.G., Duarte, M.S., Valadares Filho, S.C., Oliveira, A.S., Souza, N.K. \& Lima, J.C., 2014. Carcass characteristics of feedlot lambs fed crude glycerine contaminated with high concentrations of crude fat. Meat Sci. 96,108-113. https://doi.org/10.1016/j.meatsci.2013.06.020.

Licitra, G., Hernandez, T.M. \& Van Soest, P.J., 1996. Standardization of procedures for nitrogen fractionation of ruminant feed. Anim. Feed Sci. Technol. 57, 347-358. https://doi.org/10.1016/0377-8401(95)00837-3.

Maciel, M.V., Carvalho, F.F.R., Batista, A.M.V., Guim, A., Souza, E.J.O., Maciel, L.P.A.A., Pereira Neto,J.D. \& Lima Junior, D.M., 2015. Carcass and non-carcass characteristics of sheep fed on cassava (Manihot pseudoglaziovii Pax and K. Hoffm.). Chilean J. Agric. Res. 75, 307-312. http://dx.doi.org/10.4067/S0718-58392015000400006.

Mertens, D.R., 2002. Gravimetric determination of amylase-treated neutral detergent fiber in feeds with refluxing in beaker or crucibles: Collaborative study. J. AOAC Int. 85, 1217-1240. https://www.ncbi.nlm.nih.gov/pubmed/12477183.

Moiforay, S.K., Kallon, S., Sesay, A.R. \& Sonda, T.S., 2017. Acceptability of Gliricidia sepium as protein supplement to Panicum maximum by West African Dwarf (WAD) goats in Sierra Leone. Int. J. Sci. Res. 6, 910-916. http://dx.doi.org/10.21275/ART2017742.

Montossi, F., Font-i-Furnols, M., Del Campo, M., San Julián, R., Brito, G. \& Sañudo, C., 2013. Sustainable sheep production and consumer preference trends: Compatibilities, contradictions, and unresolved dilemmas. Meat Sci. 95, 772-789. https://doi.org/10.1016/j.meatsci.2013.04.048.

NRC, 2007. Nutrients Requirements of Small Ruminants. 8th revised edition. National Academy Press, Washington, DC.

Obeidat, B.S., Mahmoud, K.Z., Maswadeh, J.A. \& Bsoul, E.Y., 2016. Effects of feeding Atriplex halimus L. on growth performance and carcass characteristics of fattening Awassi lambs. Small Rumin. Res. 137, 65-70. https://doi.org/10.1016/j.smallrumres.2016.03.007. 
Oliveira, C.H.A., Silva, A.M., Silva, L.M., Van Tilburg, L.M., Fernandes, C.C.L., Moura, A.A., Moreno, F.B.M.B., MonteiroMoreira, A.C.O., Moreira, R.A., Bezerra, F.J. \& Rondina, D., 2015. Meat quality assessment from young goats fed for long periods with castor de-oiled cake. Meat Sci. 106,16-24. https://doi.org/10.1016/j.meatsci.2015.03.008.

Penha, F., Cano, T., Domenech, V., Alcade, M.A.J., Martos, J., Garcia-Martinez, A., Herrera, M. \& Rodero, E., 2005. Influence of sex, slaughter and carcass weight on 'non- carcass' and carcass quality in segurena lambs. Small Rum. Res. 60, 247-254. https://doi.org/10.1016/j.smallrumres.2004.12.011.

Sami, A., Shafey, T. \& Abouheif, M.A., 2013. Growth rate of carcass, non-carcass and chemical components of restricted fed and realimented growing lambs. Int. J. Agric. Biol. 15, 307-312.

SAS, 2009. Statistical Analysis System - User's guide: Statistics. Version 9.0. SAS Institute, Cary, NC, USA.

Silva Sobrinho, A.G., Purchas, R.W., Kadim, I.T. \& Yamamoto, S.M., 2005. Meat quality in lambs of different genotypes and ages at slaughter. Rev. Bras. Zootec. 34, 1070-1078. http://dx.doi.org/10.1590/S1516-35982005000300040.

Silva, D.J. \& Queiroz, A.C., 2002. Análise de Alimentos: métodos químicos e biológicos. 3rd edition. Universidade Federal de Viçosa, Viçosa.

Sniffen, C.J., O'Connor, J.D., Van Soest, P.J., Fox, D.G. \& Russell, J.B., 1992. A net carbohydrate and protein system for evaluating cattle diets: II. Carbohydrate and protein availability. J. Anim. Sci. 70, 3562-3577.

Souto, J.C.R., Araújo, G.G.L., Silva, D. S., Porto, E.R., Turco, S.H.N. \& Medeiros, A.N., 2005. Performance of sheep fed diets with increasing levels of herb salt hay (Atriplex nummularia Lindl.). Rev. Ci. Agron. 36, 376-381.

Strydom, P., Lühl, J., Kahl, C. \& Hoffman, L.C., 2016. Comparison of shear force tenderness, drip and cooking loss, and ultimate muscle $\mathrm{pH}$ of the loin muscle among grass-fed steers of four major beef crosses slaughtered in Namibia. S. Afr. J. Anim. Sci. 46, 348-359. http://dx.doi.org/10.4314/sajas.v46i4.2.

Van Soest, P.J., Robertson, J.B. \& Lewis, B.A.,1991. Symposium: carbohydrate methodology, metabolism, and nutritional implications in dairy cattle. J. Dairy Sci. 74, 3583-3597.

Ventura, Y., Eshel, A., Pasternak, D. \& Sagi, M., 2014. The development of halophyte-based agriculture: Past and present. Ann. Bot. 1, 1-12. http://dx.doi.org/10.1093/aob/mcu173.

Weiss, W.P., 1999. Energy prediction equations for ruminant feeds. In: Cornell Nutrition Conference for Feed Manufacturers, 61, Ithaca. Proceedings: Ithaca, Cornell University. pp. 176-185. 